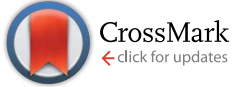

Cite this: RSC Adv., 2017, 7, 2103

Received 20th October 2016 Accepted 26th November 2016

DOI: 10.1039/c6ra25563a

www.rsc.org/advances

\title{
Effect of storage environment on hydrogen generation by the reaction of Al with water $\dagger$
}

\author{
Yin-Qiang Wang, ${ }^{\text {a }}$ Wei-Zhuo Gai, ${ }^{\mathrm{b}}$ Xia-Yu Zhang, ${ }^{\mathrm{c}}$ Hong-Yi Pan, ${ }^{\mathrm{c}}$ Zhenxiang Cheng, ${ }^{\mathrm{d}}$ \\ Pingguang $X u^{e}$ and Zhen-Yan Deng ${ }^{\star a}$
}

\begin{abstract}
Al powder was stored in saturated water vapor, oxygen, nitrogen and drying air separately for a time period of up to $\sim$ six months, the degradation behavior of Al activity was characterized by the reaction of Al with water. It was found that water vapor decreased the induction time for the beginning of Al-water reaction and reduced the total hydrogen generation per unit weight of $\mathrm{Al}$, while oxygen increased the induction time and retarded the $\mathrm{Al}$-water reaction. In contrast, the effect of nitrogen and drying air on $\mathrm{Al}$ activity was weak. The mechanism analyses indicated that water vapor promoted the hydration of the Al surface passive oxide film and sped up the reaction of Al with water, while oxygen thickened the passive oxide film of the Al surface and prolonged its hydration process. These results imply that water vapor rather than oxygen is responsible for the degradation of Al activity during storage in the atmospheric environment.
\end{abstract}

\section{Introduction}

$\mathrm{Al}$ is the most abundant metal in the earth's crust $(\sim 8.1 \%)$ and is widely used as a building material, in aircraft, industrial and civil products, paint, underwater propellant and high explosive, etc. ${ }^{\mathbf{1 - 5}}$ In the past few years, Al metal as a hydrogen-generation material has attracted considerable attention due to its relatively low cost and high productivity of $\mathrm{H}_{2}$ in that one $\mathrm{kg}$ of $\mathrm{Al}$ reacts with water to generate as much as $0.11 \mathrm{~kg} \mathrm{H}_{2} \cdot{ }^{6,7}$ Usually, there is a compact and strongly adhesive passive film on an $\mathrm{Al}$ surface upon exposure to atmosphere, inhibiting the direct reaction of $\mathrm{Al}$ with water.

In order to make $\mathrm{Al}$ react with water, different methods, based on the disruption of passive oxide film on $\mathrm{Al}$ particles, have been developed, e.g. using an alkaline solution to assist the $\mathrm{Al}$-water reaction, ${ }^{8-16}$ alloying $\mathrm{Al}$ with $\mathrm{Ga}$, In, $\mathrm{Bi}, \mathrm{Sn}, \mathrm{Ca}, \mathrm{Fe}$, etc. ${ }^{17-31}$ mechanically milling $\mathrm{Al}$ metal with special oxide, soluble inorganic salt and carbon material, ${ }^{32-47}$ and $\mathrm{Al}$ surface modification, ${ }^{\mathbf{4 8 - 5 4}}$ etc. All these approaches have made $\mathrm{Al}$ metal a promising hydrogen-generation material for portable fuel cell.

\footnotetext{
${ }^{a}$ Energy Materials \& Physics Group, Department of Physics, Shanghai University, Shanghai 200444, China. E-mail: zydeng@shu.edu.cn; Fax: +86-21-66134208; Tel: +86-21-66134334

${ }^{b}$ School of Physics \& Electronic Information, Luoyang Normal University, Luoyang 471934, China

${ }^{c}$ Qianweichang College, Shanghai University, Shanghai 200444, China

${ }^{d}$ Institute for Superconducting and Electronic Materials, University of Wollongong, North Wollongong, Wollongong, NSW 2500, Australia

'Japan Atomic Energy Agency, Tokai, Ibaraki 319-1195, Japan

$\dagger$ Electronic supplementary information (ESI) available. See DOI: 10.1039/c6ra25563a
}

Usually $\mathrm{Al}$ powder and the activated $\mathrm{Al}$ are subjected to atmospheric environment before they are used. It was found that there is an activity degradation when the activated $\mathrm{Al}$ was stored in air with a definite humidity for a time period, ${ }^{17,20-22,27,41,44}$ but the mechanism responsible for degradation is not clear so far. As the main composition of air is nitrogen, oxygen and water vapor, it is highly meaningful to clarify their roles in affecting $\mathrm{Al}$ activity, which is instructive for the selection of the suitable gas environment to store and protect $\mathrm{Al}$ from degradation. In this work, $\mathrm{Al}$ powder and the activated $\mathrm{Al}$ were stored in saturated water vapor, oxygen, nitrogen and drying air separately for a long time period. Then the $\mathrm{Al}$ activity was characterized by the reaction of $\mathrm{Al}$ with water. Finally the main mechanism leading to the Al activity degradation was analyzed.

\section{Experimental procedure}

Two kinds of Al powders with the average sizes of $1.32 \mu \mathrm{m}$ (high purity; Henan Yuanyang Aluminum Co., Henan, China) and $7.29 \mu \mathrm{m}$ (99.9\% purity; High Purity Chemical Co., Tokyo, Japan), and $\gamma-\mathrm{Al}_{2} \mathrm{O}_{3}$ powder (99.99\% purity, surface area $\sim 190 \mathrm{~m}^{2} \mathrm{~g}^{-1}$; Taimei Chemical Co., Nagano, Japan) were used in the present study. Before the storage experiment, as-purchased $1.32 \mu \mathrm{m} \mathrm{Al}$ powder was heat-treated under vacuum $\left(<10^{-4}\right.$ bar $)$ at a heating rate of $1{ }^{\circ} \mathrm{C} \min ^{-1}$ and held at $300{ }^{\circ} \mathrm{C}$ for $1 \mathrm{~h}$, in order to keep all $\mathrm{Al}$ particles with the same surface state. This heat-treated $\mathrm{Al}$ powder is referred to as HTA hereafter. At the same time, one kind of activated $\mathrm{Al}$ powder was prepared as follows. 7.29 $\mu \mathrm{m} \mathrm{Al}$ and $\gamma-\mathrm{Al}_{2} \mathrm{O}_{3}$ powders with a total weight of $15 \mathrm{~g}$ were put into a beaker with $150 \mathrm{ml}$ of absolute ethanol, and then 
ultrasonically dispersed in an ultrasonic bath (40 kHz, $100 \mathrm{~W})$ for $1 \mathrm{~h}$. The mixture suspension was dried and sieved using a 100-mesh nylon sieve, and then pressed under a unidirectional pressure of $60 \mathrm{MPa}$ to form the green compacts. The compacts were heat-treated under vacuum $\left(<10^{-4}\right.$ bar $)$ at a heating rate of $1{ }^{\circ} \mathrm{C} \min ^{-1}$ and held at $300{ }^{\circ} \mathrm{C}$ for $1 \mathrm{~h}$. The heattreated compacts were crushed into powder and sieved using a 100-mesh nylon sieve, and finally became $\gamma-\mathrm{Al}_{2} \mathrm{O}_{3}$ modified $\mathrm{Al}$ powder (GMAP). ${ }^{54}$ This GMAP has a composition of $70 \mathrm{vol} \% \mathrm{Al}+$ 30 vol\% $\gamma-\mathrm{Al}_{2} \mathrm{O}_{3}$.

The experiment for $\mathrm{Al}$ storage in water vapor was performed in a closed glass system with two connected bottles: one is with water and another is for Al storage. When the system is evacuated and then closed, liquid water will evaporate until the vapor pressure reaches saturation, and finally HTA and GMAP are stored in the bottle with saturated water vapor. The experiment for $\mathrm{Al}$ storage in oxygen or nitrogen was performed in a cylindrical vessel made of stainless steel. The vessel has an entrance and an exit, the exit is for evacuation and the entrance is for filling oxygen or nitrogen. Both the oxygen and nitrogen pressures for Al storage are 2 bars. All the processes of taking the samples from the vessel were done in a large argon-filled glove box, in order to protect HTA and GMAP from contact with air. The experiment for Al storage in drying air was performed in a drying cabinet with a constant humidity of $\sim 25 \%$. All the storage experiments were done at room temperature. The vessels' structures and detailed storage procedure for HTA and GMAP are given in the ESI. $\dagger$

The hydrogen-generation experiment of HTA or GMAP with water was carried out in a closed glass reactor (Fig. 1 of ref. 55). All the hydrogen-generation tests were conducted at a temperature of $35{ }^{\circ} \mathrm{C}$, which was controlled by a thermostat water bath with an accuracy of $\pm 1{ }^{\circ} \mathrm{C} .1 .0 \mathrm{~g}$ of HTA or GMAP was used in each test, which was suspended in $250 \mathrm{ml}$ of deionized water. A magnetic agitation bar with a speed of $\sim 500 \mathrm{rpm}$ was used to stir the mixture of water and HTA or GMAP. At the beginning, the reactor was filled by the ambient air and the initial gas pressure was 1 bar. As the Al-water reaction produces only one kind of gas, i.e. $\mathrm{H}_{2}{ }^{49}$ the reaction evolution of $\mathrm{Al}$ with water could be determined by the gas pressure in the reactor using the ideal-gas equation

$$
\alpha=\frac{\left(P-P_{\text {initial }}\right)\left(V_{\text {reactor }}-V_{\mathrm{H}_{2} \mathrm{O}}-V_{\mathrm{Al}}\right)}{n_{0} R T},
$$

where $\alpha$ is the hydrogen yield; $P$ and $P_{\text {initial }}$ are the total gas pressure and initial gas pressure in the reactor, respectively; $V_{\text {reactor }}, V_{\mathrm{H}_{2} \mathrm{O}}$ and $V_{\mathrm{Al}}$ are the volumes of the reactor, water and $\mathrm{Al}$ powder, respectively; $n_{0}$ is the theoretical hydrogen moles by reacting all of the Al metal in HTA or GMAP; $R$ is the gas constant and $T$ is the gas temperature. At least two identical tests were carried out to check the reproducibility of each hydrogen-generation curve. An X-ray diffractometry was used to analyze the phases of the as-received HTA, GMAP and those after storage in different gas environments. Scanning electron microscopy (SEM) was used to observe the morphologies of HTA and GMAP before and after storage.

\section{Results and discussion}

Fig. 1 shows the morphologies of as-received HTA and those after storage in different gas environments for a time period. It can be seen that as-received heat-treated $\mathrm{Al}$ particles are smooth and there are some very fine white particles covering on their surfaces (Fig. 1(a)). These fine particles are believed to be $\gamma$ $\mathrm{Al}_{2} \mathrm{O}_{3}$ grains and their agglomerates, because $\mathrm{Al}$ surface passive film has complicated phase constituents, including metastable $\mathrm{Al}_{2} \mathrm{O}_{3}$, boehmite and bayerite, etc., which begin to transform into $\gamma-\mathrm{Al}_{2} \mathrm{O}_{3}$ phase at a temperature of $\sim 180{ }^{\circ} \mathrm{C}$. At the heattreatment temperature of $300{ }^{\circ} \mathrm{C}$, all the constituents in $\mathrm{Al}$ surface passive film are transformed into $\gamma-\mathrm{Al}_{2} \mathrm{O}_{3}$ phase, while a new surface dense passive film is formed after the heat-treated $\mathrm{Al}$ particles are re-exposed to air. ${ }^{54}$ This guarantees that all the as-received HTA particles have the same surface state. After storage of HTA in different gas environment for 3-6 months, it can be seen that the morphology of HTA particles in oxygen, nitrogen and drying air has no observable change (Fig. 1(c)-(e)), while there are many piece-like layered structures covering on $\mathrm{Al}$ particles after HTA was stored in water vapor for $\sim 5$ months (Fig. 1(b)).

Fig. 2 shows the morphologies of as-received GMAP and those after storage in different gas environment for a time period. It can be seen that as-received GMAP particle surfaces are almost completely covered by fine $\gamma-\mathrm{Al}_{2} \mathrm{O}_{3}$ grains (Fig. 2(a)), the same as previous work. ${ }^{54}$ After storage of GMAP in different gas environment for 1.5-5 months, it can be seen that the morphology of GMAP particles in oxygen, nitrogen and drying air has no observable change (Fig. 2(c)-(e)), while GMAP particle surfaces become a little bit dense and piece-like after it was stored in water vapor for $\sim 5$ months (Fig. 2(b)), similar to the results in Fig. 1.

Fig. 3 shows $\mathrm{H}_{2}$ evolution from deionized water at a thermostat temperature of $35{ }^{\circ} \mathrm{C}$ using as-received HTA and those stored in water vapor, oxygen, nitrogen and air for a similar time, respectively. It can be seen that water vapor reduces the induction time for the beginning of $\mathrm{Al}$-water reaction, while oxygen increases the induction time. The effect of nitrogen and drying air on $\mathrm{Al}$ activity is weak.

Fig. 4 shows the $\mathrm{H}_{2}$ evolution from deionized water at a thermostat temperature of $35{ }^{\circ} \mathrm{C}$ using HTA and those stored in water vapor, oxygen, nitrogen and drying air for different time, respectively, where the data in the parentheses are the environment temperatures during $\mathrm{Al}$-water reaction tests. It can be seen that when HTA is stored in water vapor, the induction time for the beginning of $\mathrm{Al}-$ water reaction decreases and the total hydrogen generation per unit weight of $\mathrm{Al}$ is reduced. With the increase in storage time, the above tendency is more obvious. When the storage time in water vapor is $\sim 6$ months, there is almost no induction time and the total hydrogen generation is $<20 \%$ of that of as-received HTA (Fig. 4(a)).

The effect of oxygen on $\mathrm{Al}$ activity is different from that of water vapor (Fig. 4(b)). The induction time for the beginning of $\mathrm{Al}-$ water reaction increases and the total hydrogen generation per unit weight of $\mathrm{Al}$ almost has no any change. This phenomenon is 

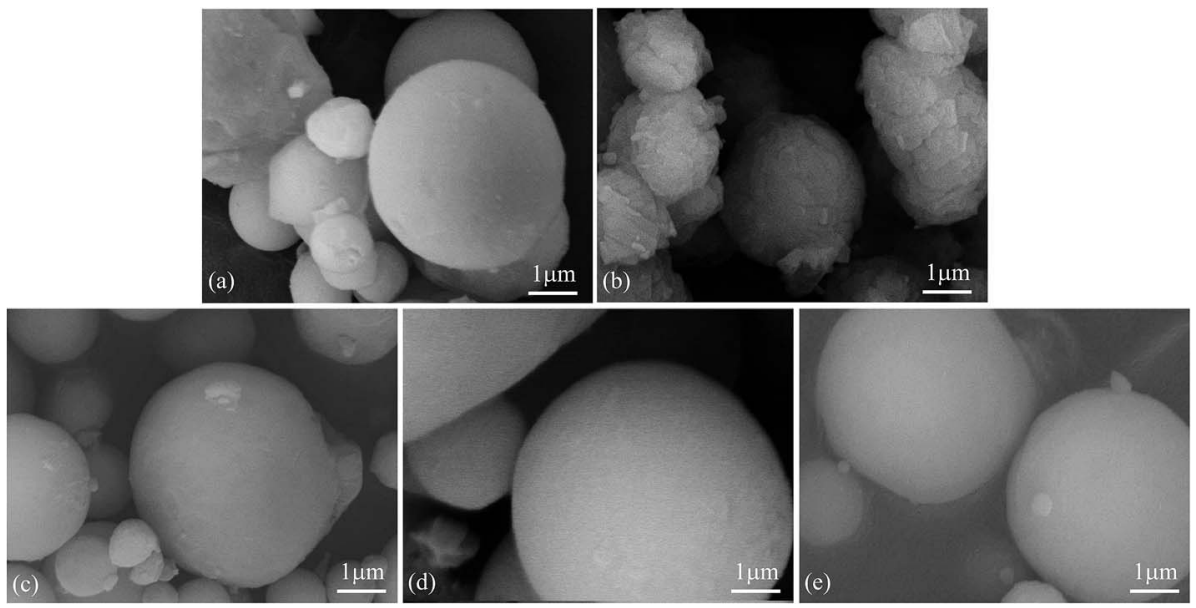

Fig. 1 SEM micrographs of as-received HTA (a), that in (a) stored in water vapor for 158 days (b), in oxygen for 103 days (c), in nitrogen for 103 days (d) and in air for 189 days (e).

obvious after HTA was stored in oxygen for 8 and 47 days. As our experiment was performed from winter to spring, the room temperature has a large fluctuation. Previous work ${ }^{56}$ has confirmed that the environment temperature has an influence on the practical temperature of water in the reactor, because the thermal diffusion of the reactor is related to the environment temperature. When the environment temperature increases, the water temperature in the reactor increases even the thermostat bath temperature is constant. This is why the induction time of as-received HTA at an environment temperature of $25{ }^{\circ} \mathrm{C}$ is shorter than that at $11.5^{\circ} \mathrm{C}$ (Fig. 4(b)). At a similar environment temperature $\left(\sim 25{ }^{\circ} \mathrm{C}\right)$, the induction time of HTA stored in oxygen for 178 days is still longer than that of as-received HTA, as shown in Fig. 4(b).

Fig. 4(c) and (d) indicate that the total hydrogen generation per unit weight of Al almost has no change after HTA was stored in nitrogen and drying air for 6 and 5 months, respectively. But there is a change in induction time after HTA was stored in nitrogen and drying air for different time period. It is noticed

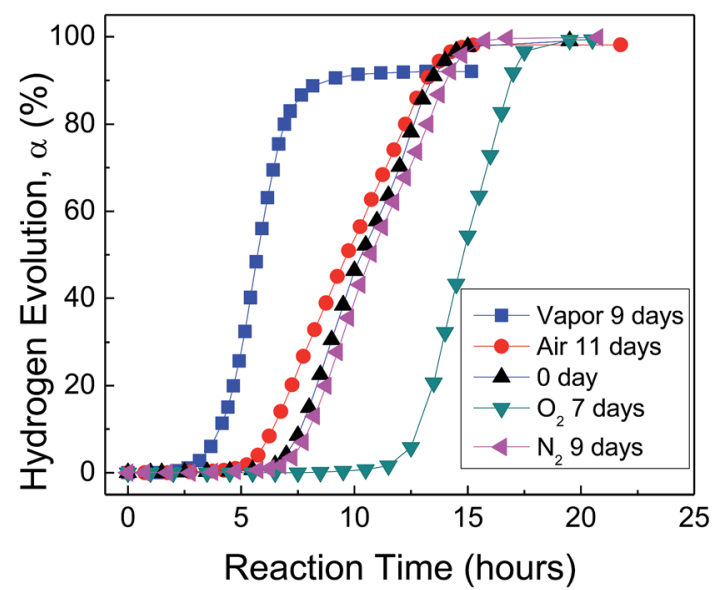

Fig. $3 \mathrm{H}_{2}$ evolution from deionized water at a thermostat temperature of $35{ }^{\circ} \mathrm{C}$ using as-received HTA and those stored in water vapor, oxygen $\left(\mathrm{O}_{2}\right)$, nitrogen $\left(\mathrm{N}_{2}\right)$ and air for a similar time, respectively. The environment temperature during $\mathrm{Al}$-water reaction tests is $10^{\circ} \mathrm{C}$.

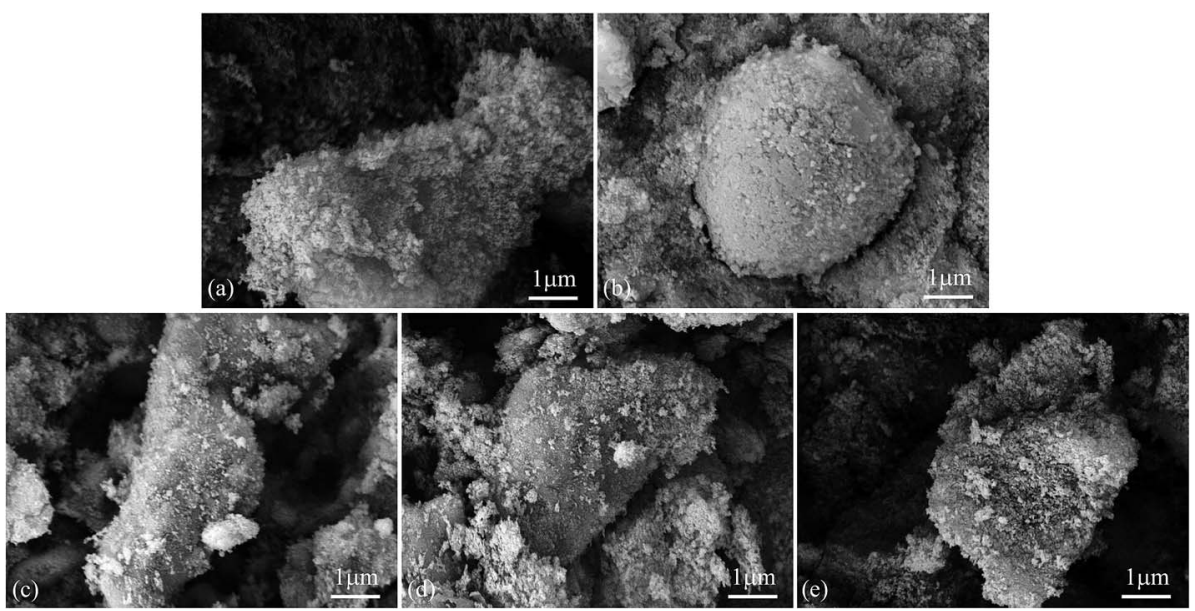

Fig. 2 SEM micrographs of as-received GMAP (a), that in (a) stored in water vapor for 152 days (b), in oxygen for 127 days (c), in nitrogen for 50 days (d) and in air for 94 days (e). 

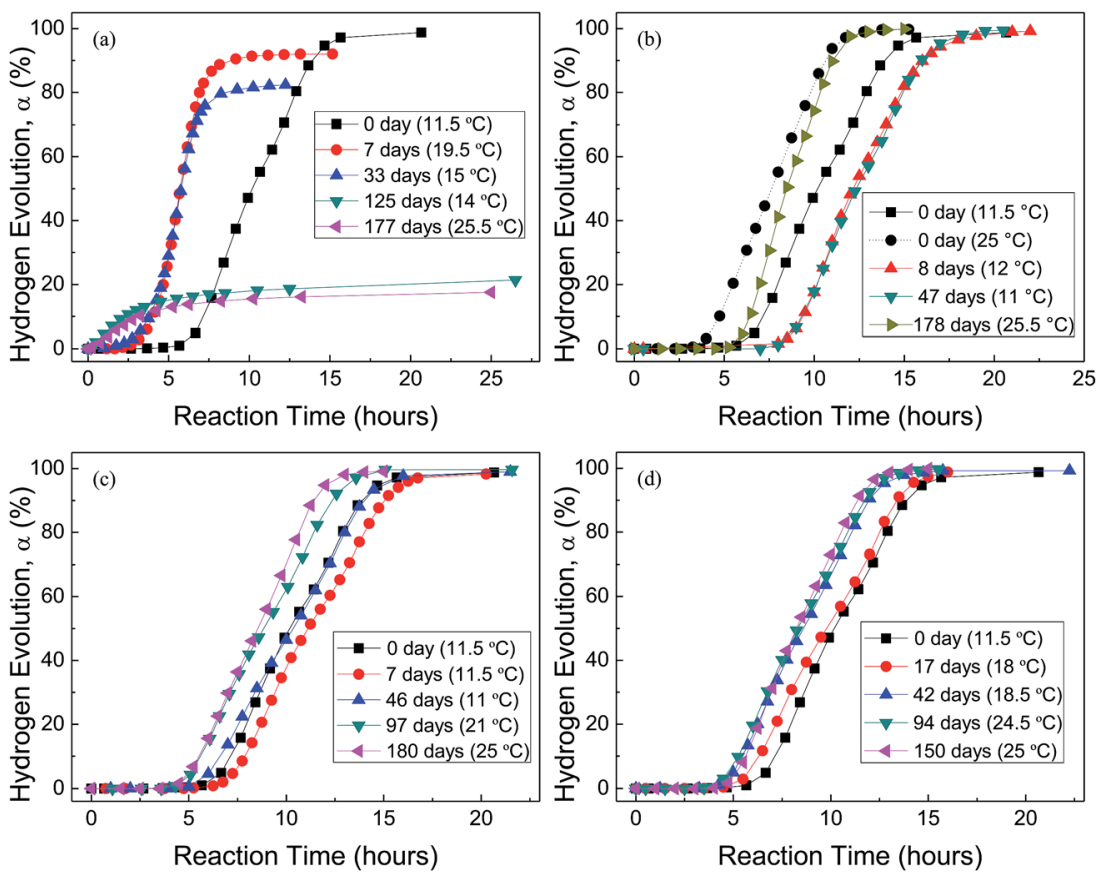

Fig. $4 \mathrm{H}_{2}$ evolution from deionized water at a thermostat temperature of $35^{\circ} \mathrm{C}$ using as-received $\mathrm{HTA}$ and those stored in water vapor (a), in oxygen (b), in nitrogen (c) and in air (d) for different time, respectively. The data in the parentheses are the environment temperatures during Alwater reaction tests.

that this change is basically consistent with the change in environment temperature during $\mathrm{Al}$-water reaction test, i.e. the change in induction time results from the change in environment temperature. Therefore, if the environment temperature is considered, it seems that the effect of nitrogen and drying air on $\mathrm{Al}$ activity is weak.

Fig. 5 shows the $\mathrm{H}_{2}$ evolution from deionized water at a thermostat temperature of $35^{\circ} \mathrm{C}$ using GMAP and those stored in water vapor, oxygen, nitrogen and drying air for different time, respectively. GMAP is an activated $\mathrm{Al}$, which almost has no induction time for the beginning of Al-water reaction. ${ }^{54}$ Therefore, the effect of different gas environment on the induction time of GMAP is small and unobservable. However, the total hydrogen generation per unit weight of $\mathrm{Al}$ decreases with increasing the storage time in water vapor. When the storage time in water vapor is $\sim 6$ months, the total hydrogen generation is $\sim 30 \%$ of that of as-received GMAP (Fig. $5(\mathrm{a})$ ). The effect of oxygen and nitrogen on the total hydrogen generation of GMAP is negligible even the storage time is up to 6 months (Fig. 5(b) and (c)). Moreover, the hydrogen-generation rate decreases after GMAP was stored in oxygen for 15 days (Fig. 5(b)), it probably is due to the lower environment temperature $\left(4{ }^{\circ} \mathrm{C}\right)$ during $\mathrm{Al}-$ water reaction test. It is noticed that drying air has a small influence on the total hydrogen generation of GMAP. When the storage time in drying air is $>3$ months, the total hydrogen generation keeps $\sim 95 \%$ of that of as-received GMAP (Fig. 5(d)).

Fig. 6 and 7 show the X-ray diffraction patterns of asreceived HTA and GMAP, and those after storage in different gas environment for a time period. It can be seen that as-received HTA only has Al metal phase, while as-received GMAP has a composition of $\mathrm{Al}$ and $\gamma-\mathrm{Al}_{2} \mathrm{O}_{3}$. The phase of the white particles on as-received HTA particle surfaces is not observed, the possible reason is that their amount is too small to be detected by X-ray diffraction (Fig. 6(a)). The phase constituents in HTA and GMAP have no observable change after they were stored in oxygen, nitrogen and drying air for several months except for water vapor. There is a bayerite $\left(\mathrm{Al}(\mathrm{OH})_{3}\right)$ phase in HTA and GMAP after they were stored in water vapor for $>3$ months (Fig. 6(b) and 7(b)), indicating that part of their $\mathrm{Al}$ was consumed by the following reaction

$$
2 \mathrm{Al}+6 \mathrm{H}_{2} \mathrm{O} \rightarrow 2 \mathrm{Al}(\mathrm{OH})_{3}+3 \mathrm{H}_{2} \uparrow .
$$

In Fig. 5(d), although the total hydrogen generation of GMAP decreases to $\sim 95 \%$ of that of as-received after it was stored in drying air for $>3$ months, the bayerite phase is not observed in Fig. 7(e), it is believed to be due to its low amount.

Previous mechanism analyses revealed that there is a hydration reaction in the passive oxide film on $\mathrm{Al}$ particle surface when Al particle is put into water. ${ }^{49}$ This hydration process determines the induction time for the beginning of Al-water reaction. That $\gamma-\mathrm{Al}_{2} \mathrm{O}_{3}$ grains on GMAP particle surfaces improve the Al-water reaction dynamics results from the catalytic effect of $\gamma-\mathrm{Al}_{2} \mathrm{O}_{3}$ on this hydration process, ${ }^{54}$ leading to almost no induction time for GMAP.

Based on the above experimental observation, a conceptual model is proposed to explain the change of Al particle after storage in oxygen and water vapor, respectively, as shown in Fig. 8. It should be mentioned that $\mathrm{Al}$ surface passive film is very thin and with thinness in several nanometer, ${ }^{57}$ which is difficult to be detected by X-ray diffraction (Fig. 6(a)). When Al 

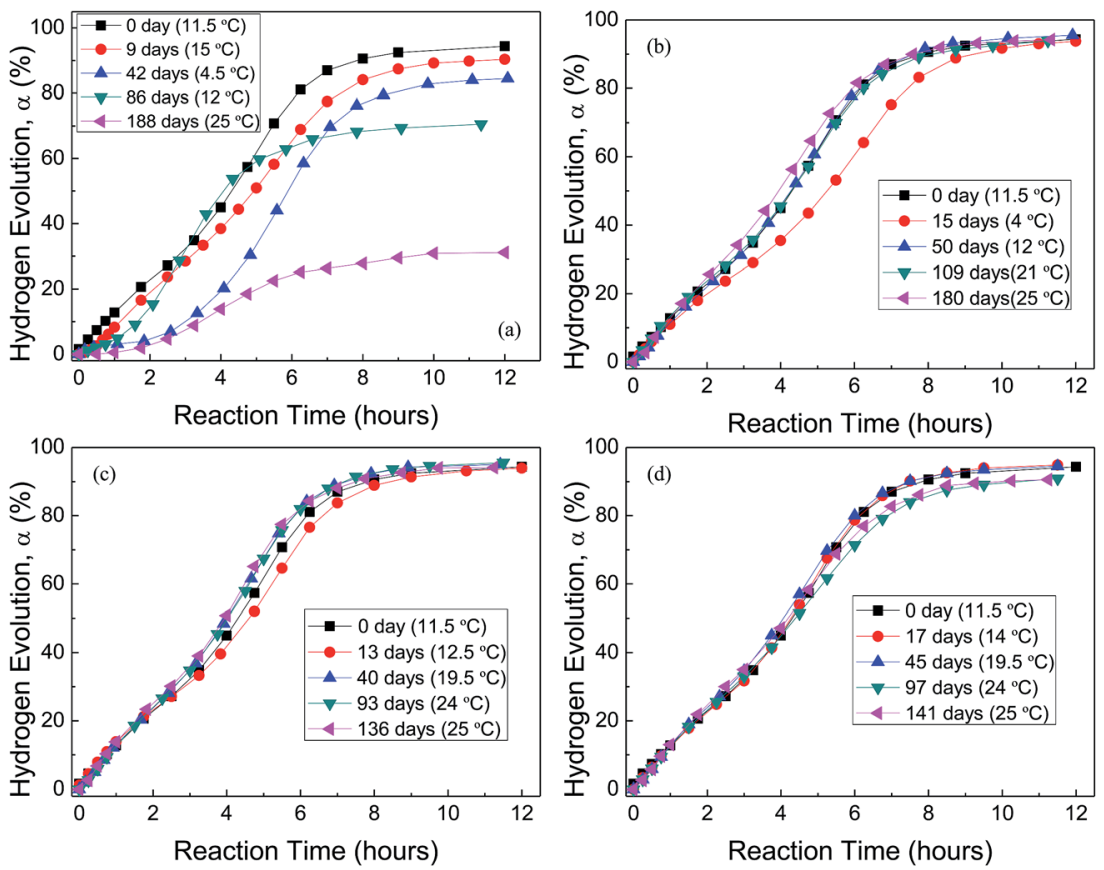

Fig. $5 \mathrm{H}_{2}$ evolution from deionized water at a thermostat temperature of $35^{\circ} \mathrm{C}$ using as-received GMAP and those stored in water vapor (a), in oxygen (b), in nitrogen (c) and in air (d) for different time, respectively. The data in the parentheses are the environment temperatures during Alwater reaction tests.

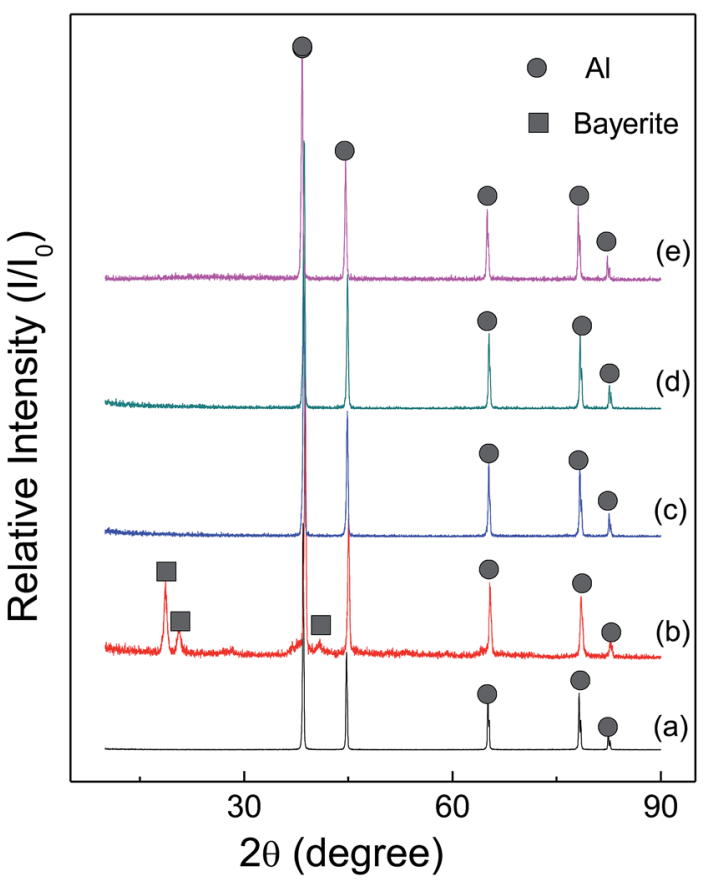

Fig. 6 X-ray patterns of as-received HTA (a), that in (a) stored in water vapor for 158 days (b), in oxygen for 103 days (c), in nitrogen for 103 days (d) and in air for 189 days (e).

particle is stored in oxygen, oxygen will transport through the passive film ${ }^{57}$ and contact $\mathrm{Al}$ inside, and then reacts with $\mathrm{Al}$ to form alumina, leading to a thickness increase in the passive film (Fig. 8(b)). The thickness increase in the passive film will

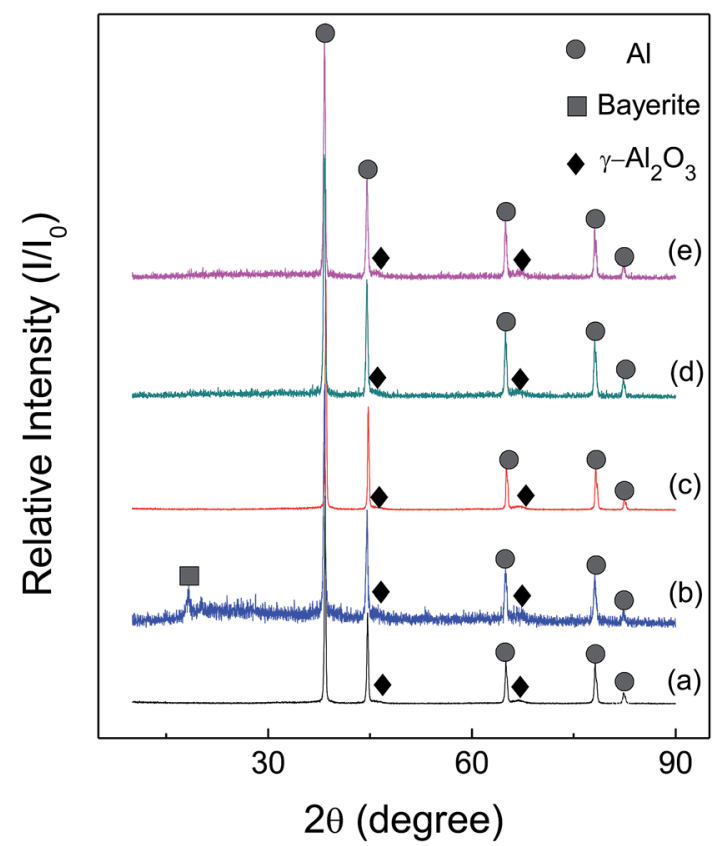

Fig. 7 X-ray patterns of as-received $\operatorname{GMAP}(a)$, that in (a) stored in water vapor for 94 days (b), in oxygen for 152 days (c), in nitrogen for 50 days (d) and in air for 127 days (e).

prolong the hydration process and results in a longer induction time than as-received HTA, as shown in Fig. 3 and 4(b). As GMAP almost has no induction time, the effect of oxygen on its $\mathrm{Al}$ reaction dynamics is not obvious, as shown in Fig. 5(b). 


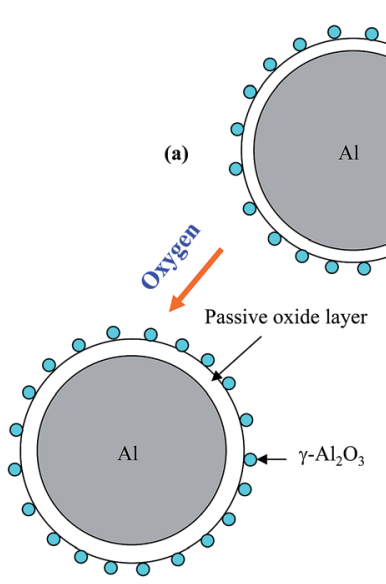

(b)
Passive oxide layer
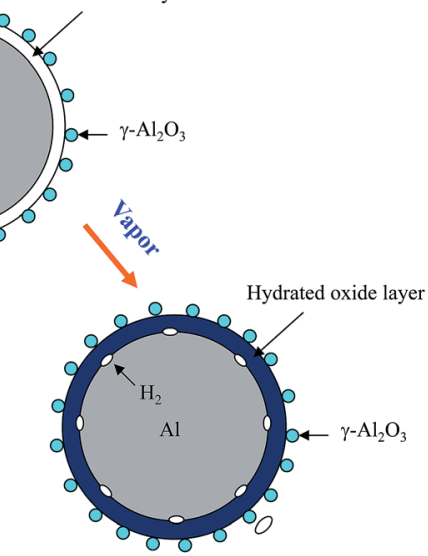

(c)
Fig. 8 Schematic representation of the surface structure of an asreceived HTA particle (a) and the change after it is stored in oxygen (b) and in water vapor (c) for a time period, respectively.

When $\mathrm{Al}$ particle is stored in water vapor, water molecules will hydrate with the $\mathrm{Al}$ surface passive oxide film and reach the surface of $\mathrm{Al}$ inside, ${ }^{49}$ and then react with $\mathrm{Al}$ to generate hydrogen (Fig. 8(c)). With increasing the storage time in water vapor, more $\mathrm{Al}$ in HTA and GMAP is consumed. This is why the induction time of HTA decreases and the total hydrogen generation for both HTA and GMAP is reduced, as shown in Fig. 4(a) and 5(a). The above speculation was also confirmed by X-ray diffraction (Fig. 6(b) and 7(b)) and SEM observation. The piece-like structure on HTA and GMAP particle surfaces (Fig. 1(b) and 2(b)) should be the reaction byproduct bayerite.

As nitrogen does not react with $\mathrm{Al}$ at room temperature, the $\mathrm{Al}$ activity almost has no change after HTA and GMAP are stored in nitrogen environment, as shown in Fig. 4(c) and 5(c), which was also confirmed by X-ray diffraction (Fig. 6(d) and 7(d)) and SEM observation (Fig. 1(d) and 2(d)). In this work, drying air has a humidity of $\sim 25 \%$, there should be a synergic effect of oxygen and water vapor on Al activity when HTA and GMAP are stored in drying air. Oxygen increases the thickness of $\mathrm{Al}$ surface oxide film and prolongs the reaction induction time, however water vapor promotes the hydration process and speeds up the $\mathrm{Al}-$ water reaction. It seems that this synergic effect on the $\mathrm{Al}$ activity is weak even HTA and GMAP were stored in drying air for $\sim 5$ months (Fig. 3, 4(d) and 5(d)), which was also confirmed by X-ray diffraction (Fig. 6(e) and 7(e)) and SEM observation (Fig. 1(e) and 2(e)). Of course, the Al activity degradation of GMAP in drying air is faster than that of HTA due to the catalytic effect of $\gamma-\mathrm{Al}_{2} \mathrm{O}_{3}$ on the hydration process (see Fig. 4(d) and 5(d)). The above results imply that $\mathrm{Al}$ metal can be stored in nitrogen, oxygen and drying air, in order to keep its activity.

\section{Conclusions}

In this work, the effect of storage gas environment on Al activity for a time period up to $\sim 6$ months was investigated. It was found that oxygen increases the thickness of $\mathrm{Al}$ surface passive film and prolongs its hydration process, leading to a longer induction time for the beginning of Al-water reaction (HTA). Water vapor promotes the hydration process of $\mathrm{Al}$ surface passive film and speeds up the Al-water reaction, leading to a decrease in total hydrogen generation per unit amount of $\mathrm{Al}$ for both HTA and GMAP. The effect of nitrogen and drying air on the $\mathrm{Al}$ activity is weak, because nitrogen does not react with $\mathrm{Al}$ at room temperature and there is a lower humidity in drying air. Our results indicate that water vapor rather than oxygen is responsible for the degradation of $\mathrm{Al}$ activity during storage in atmospheric environment.

\section{Acknowledgements}

We would like to thank the financial support of Shanghai Key Laboratory of High Temperature Superconductors (No. 14DZ2260700).

\section{References}

1 D. F. Waters and C. P. Cadou, J. Power Sources, 2013, 221, 272-283.

2 L. Bai, F. Fang, Y. Y. Zhao, Y. G. Liu, J. P. Li, G. Y. Huang and H. Y. Sun, RSC Adv., 2014, 4, 43039-43046.

3 W. Z. Gai, Z. Y. Deng and Y. Shi, RSC Adv., 2015, 5, 8422384231.

4 G. Y. Huang, S. M. Xu, Y. Yang, H. Y. Sun and Z. H. Xu, RSC Adv., 2016, 6, 10763-10774.

5 G. Y. Huang, X. Y. Guo, X. Cao, Q. H. Tian and H. Y. Sun, Nano Energy, 2016, 28, 338-345.

6 Z. Y. Deng, J. M. F. Ferreira and Y. Sakka, J. Am. Ceram. Soc., 2008, 91, 3825-3834.

7 X. N. Huang, T. Gao, X. L. Pan, D. Wei, C. J. Lv, L. S. Qin and Y. X. Huang, J. Power Sources, 2013, 229, 133-140.

8 J. Macanás, L. Soler, A. M. Candela, M. Muñoz and J. Casado, Energy, 2011, 36, 2493-2501.

9 H. B. Dai, G. L. Ma, H. J. Xia and P. Wang, Energy Environ. Sci., 2011, 4, 2206-2212.

10 M. K. Yu, M. J. Kim, B. Y. Yoon, S. K. Oh, D. H. Nam and H. S. Kwon, Int. J. Hydrogen Energy, 2014, 39, 19416-19423.

11 A. Saffarzadeh, N. Arumugam and T. Shimaoka, Int. J. Hydrogen Energy, 2016, 41, 820-831.

12 B. Yuan, S. C. Tan and J. Liu, Int. J. Hydrogen Energy, 2016, 41, 1453-1459.

13 A. O. Dudoladov, O. A. Buryakovskaya, M. S. Vlaskin, A. Z. Zhuk and E. I. Shkolnikov, Int. J. Hydrogen Energy, 2016, 41, 2230-2237.

14 C. Y. Ho and C. H. Huang, Int. J. Hydrogen Energy, 2016, 41, 3741-3747.

15 J. L. Lopez-Miranda and G. Rosas, Int. J. Hydrogen Energy, 2016, 41, 4054-4059.

16 X. H. Yang, B. Yuan and J. Liu, Int. J. Hydrogen Energy, 2016, 41, 6193-6199.

17 O. V. Kravchenko, K. N. Semenenko, B. M. Bulychev and K. B. Kalmykov, J. Alloys Compd., 2005, 397, 58-62.

18 M. Q. Fan, F. Xu and L. X. Sun, Int. J. Hydrogen Energy, 2007, 32, 2809-2815. 
19 M. Q. Fan, L. X. Sun and F. Xu, Energy, 2010, 35, 2922-2926. 20 A. V. Ilyukhina, O. V. Kravchenko, B. M. Bulychev and E. I. Shkolnikov, Int. J. Hydrogen Energy, 2010, 35, 1905-1910. 21 Z. W. Zhao, X. Y. Chen and M. M. Hao, Energy, 2011, 36, 2782-2787.

22 J. T. Ziebarth, J. M. Woodall, R. A. Kramer and G. Choi, Int. J. Hydrogen Energy, 2011, 36, 5271-5279.

23 X. Y. Hu, G. Z. Zhu, Y. J. Zhang, Y. M. Wang, M. S. Gu, S. Yang, P. X. Song, X. J. Li, H. J. Fang, G. S. Jiang and Z. F. Wang, Int. J. Hydrogen Energy, 2012, 37, 11012-11020.

24 H. H. Wang, Y. Chang, S. J. Dong, Z. F. Lei, Q. B. Zhu, P. Luo and Z. X. Xie, Int. J. Hydrogen Energy, 2013, 38, 1236-1243.

25 T. T. He, W. Wang, D. M. Chen and K. Yang, Int. J. Hydrogen Energy, 2014, 39, 684-691.

26 S. Elitzur, V. Rosenband and A. Gany, Int. J. Hydrogen Energy, 2014, 39, 6328-6334.

27 X. Y. Chen, Z. W. Zhao, X. H. Liu, M. M. Hao, A. L. Chen and Z. Y. Tang, J. Power Sources, 2014, 254, 345-352.

28 T. P. Huang, Q. Gao, D. Liu, S. N. Xu, C. B. Guo, J. J. Zou and C. D. Wei, Int. J. Hydrogen Energy, 2015, 40, 2354-2362.

29 W. J. Yang, T. Y. Zhang, J. H. Zhou, W. Shi, J. Z. Liu and K. F. Cen, Energy, 2015, 88, 537-543.

30 W. J. Yang, T. Y. Zhang, J. Z. Liu, Z. H. Wang, J. H. Zhou and K. F. Cen, Energy, 2015, 93, 451-457.

31 W. J. Yang, X. W. Liu, J. Z. Liu, Z. H. Wang, J. H. Zhou and K. F. Cen, Int. J. Hydrogen Energy, 2016, 41, 7927-7934.

32 E. Czech and T. Troczynski, Int. J. Hydrogen Energy, 2010, 35, 1029-1037.

33 K. Mahmoodi and B. Alinejad, Int. J. Hydrogen Energy, 2010, 35, 5227-5232.

34 H. Luo, J. Liu, X. X. Pu, J. Liang, Z. J. Wang, F. J. Wang, K. Zhang, Y. J. Peng, B. Xu, J. H. Li and X. B. Yu, J. Am. Ceram. Soc., 2011, 94, 3976-3982.

35 P. Dupiano, D. Stamatis and E. L. Dreizin, Int. J. Hydrogen Energy, 2011, 36, 4781-4791.

36 H. W. Wang, H. W. Chung, H. T. Teng and G. Z. Cao, Int. J. Hydrogen Energy, 2011, 36, 15136-15144.

37 X. N. Huang, C. J. Lv, Y. Wang, H. Y. Shen, D. Chen and Y. X. Huang, Int. J. Hydrogen Energy, 2012, 37, 7457-7463.

38 H. T. Teng, T. Y. Lee, Y. K. Chen, H. W. Wang and G. Z. Cao, J. Power Sources, 2012, 219, 16-21.
39 S. S. Razavi-Tousi and J. A. Szpunar, Int. J. Hydrogen Energy, 2013, 38, 795-806.

40 H. Q. Nie, S. S. Zhang, M. Schoenitz and E. L. Dreizin, Int. J. Hydrogen Energy, 2013, 38, 11222-11232.

41 X. Y. Chen, Z. W. Zhao, M. M. Hao and D. Z. Wang, J. Power Sources, 2013, 222, 188-195.

42 Y. Y. Jia, J. Shen, H. X. Meng, Y. M. Dong, Y. J. Chai and N. Wang, J. Alloys Compd., 2014, 588, 259-264.

43 F. Xu, L. X. Sun, X. F. Lan, H. L. Chu, Y. J. Sun, H. Y. Zhou, F. Li, L. N. Yang, X. L. Si, J. Zhang, S. Walter and Z. Gabelica, Int. J. Hydrogen Energy, 2014, 39, 5514-5521.

44 S. S. Razavi-Tousi and J. A. Szpunar, Metall. Mater. Trans. E, 2014, 1, 247-256.

45 Y. A. Liu, X. H. Wang, H. Z. Liu, Z. H. Dong, S. Q. Li, H. W. Ge and M. Yan, Energy, 2014, 72, 421-426.

46 Y. A. Liu, X. H. Wang, H. Z. Liu, Z. H. Dong, S. Q. Li, H. W. Ge and M. Yan, Energy, 2015, 84, 714-721.

47 Y. A. Liu, X. H. Wang, H. Z. Liu, Z. H. Dong, S. Q. Li, H. W. Ge and M. Yan, Energy, 2015, 89, 907-913.

48 Z. Y. Deng, Y. F. Liu, Y. Tanaka, J. H. Ye and Y. Sakka, J. Am. Ceram. Soc., 2005, 88, 977-979.

49 Z. Y. Deng, J. M. F. Ferreira, Y. Tanaka and J. H. Ye, J. Am. Ceram. Soc., 2007, 90, 1521-1526.

50 Z. Y. Deng, Y. B. Tang, L. L. Zhu, Y. Sakka and J. H. Ye, Int. J. Hydrogen Energy, 2010, 35, 9561-9568.

51 C. S. Fang, W. Z. Gai and Z. Y. Deng, J. Am. Ceram. Soc., 2014, 97, 44-47.

52 N. Wang, H. X. Meng, Y. M. Dong, Z. L. Jia, L. J. Gao and Y. J. Chai, Int. J. Hydrogen Energy, 2014, 39, 16936-16943.

53 Y. Yang, W. Z. Gai, Z. Y. Deng and J. G. Zhou, Int. J. Hydrogen Energy, 2014, 39, 18734-18742.

54 W. Z. Gai, Y. Shi, Z. Y. Deng and J. G. Zhou, Int. J. Hydrogen Energy, 2015, 40, 12057-12062.

55 W. Z. Gai, W. H. Liu, Z. Y. Deng and J. G. Zhou, Int. J. Hydrogen Energy, 2012, 37, 13132-13140.

56 G. H. Liang, W. Z. Gai, Z. Y. Deng, P. G. Xu and Z. X. Cheng, RSC Adv., 2016, 6, 35305-35314.

57 B. C. Bunker, G. C. Nelson, K. R. Zavadil, J. C. Barbour, F. D. Wall, J. P. Sullivan, et al., J. Phys. Chem. B, 2002, 106, 4705-4713. 